\section{A Review of Space Research}

The Report of the Summer Study conducted under the Auspices of the Space Science Board of the National Academy of Sciences at the State University of Iowa, Iowa City, Iowa, June 17-August 10, 1962. Pp. iv +577. (Washington, D.C.: National Academy of SciencesNational Research Council, 1962.) 4 dollars.

T OWARDS the end of 1961 the U.S. National Aeronautics and Space Administration and the Space Science Board decided to arrange for a thorough review of the Administration's programme for space science. Accordingly, about a hundred scientists from universities and industry, and a rather smaller number from National Aeronautics and Space Administration and other official organizations, gathered for a summer school at the University of Iowa during June-August, 1962, with Prof. Van Allen as chairman. After some introductory sessions, the participants broke up into working groups on various specialized topics, and their reports occupy much of this 2-litre paperback volume.

The subjects of the main working groups were astronomy, celestial mechanics, lunar and planetary research, atmospheres of the planets, bistatic radar astronomy, particles and fields, meteorological rockets and satellites, biology, space probe sterilization, man's scientific role in space exploration, the allocation of payload space, scientific uses of spacecraft launched by other Federal agencies, international co-operation, and social implications of the space programme. In addition to the reports of these groups and their sub-groups, there are various factual appendixes and a discussion of the relationships between the National Aeronautics and Space Administration and the universities.

The volume is impressive in two ways - as a record of a thorough and perhaps unique piece of national selfquestioning, and as a fine vindication of the Administration's programme for space science. (The worth of the man-in-space project was not directly discussed.) None of the working groups produced serious objections, though various changes in emphasis were suggested. One could make the criticism that reactions are bound to be favourable if a group of specialists is asked to approve a series of experiments in its own speciality; but it would have been impracticable and chaotic to have invited dissenting outsiders. As well as being impressive, the book is useful as a work of reference: several of the summaries of the present state of knowledge, for example, in the "Particles and Fields" section, are excellent; and countries now contemplating a start on space research will find it helpful to have the arguments in favour of each of the National Aeronautics and Space Administration projects so forcefully summarized.

D. G. King-Hene

The Birds of the British Isles

By Dr. David Armitage Bannerman. Vol. 11: Glareolidao-Otididao-Burhinidae-Gruidae-Laridae. Pp. $\mathrm{xv}+368+32$ plates. (Edinburgh and London: Oliver and Boyd, Ltd., 1962.) 63s. net.

R. BANNERMAN'S penultimate volume completes his treatment of the plover-like birds, proceeds to the bustards and the crane, and then devotes some three-quarters of its space to the terns and gulls. This arrangement, incidentally, is an unusual one in these days, as most ornithologists regard the plovers and the gulls as closely related. The remnant of 'waders' included here, representing two minor families, consists of one courser, two pratincoles, and the stone-curlew-all except the last mentioned being only rare vagrants to the British Isles. The three bustards have similar status, and the crane that of an irregular visitor on migration, although the great bustard and the crane-two magnificent species-have histories as native British birds. With the terns and gulls we come to a solid block of common British birds, with others of lesser status. Each of these two sub-families is introduced by a general article on the behaviour of the included species, contributed by Dr. M. Cullen for the terns and by Dr. Niko Tinbergen for the gulls. The whole article on the kittiwake is contributed by Dr. J. Coulson, and that on Sabine's gull by Prof. G. M. Sutton of Oklahoma. Shorter specialist contributions come from as far afield as Canada and Russia, Portugal and Hungary. All these are welded by the author into a general account that is both very readable and fully authoritative.

LANDSBOROUGH THOMSON

\section{Between Pacific Tides}

An Account of the Habits and Habitats of some Five Hundred of the Common, Conspicuous Sea-Shore Invertebrates of the Pacific Coast between Sitka, Alaska, and North Mexico. By Edward F. Ricketts and Jack Calvin. Third edition, revised. Pp. xiii +516 . (Stanford, Calif.: Stanford University Press; London: Oxford University Press, 1962.) 70s, net.

THIS successful book on the littoral fauna and flora of the Pacific coast of North America has been revised by Dr. Joel Hedgpeth, director of the Pacific Marine Station at Dillon Beach, California. Ricketts's text for beginners has been preserved; it deals with the inhabitants of rocky shores, sandy beaches and sand flats, estuaries, mud flats and wharf piles. Dr. Hedgpeth has withdrawn the chapter on plankton and added chapters on intertidal zonation, immigrants to the area, and conditions beyond the tides.

An appendix of nearly 100 pages is for the trained biologist, and contains a classification of the animal kingdom, a list of the chief species in each phylum, with references to the text, and a full bibliography.

Nearly 500 common littoral species are described, illustrated by 107 drawings, 46 plates of photographs, 9 pages of drawings of seaweeds and a coloured frontispiece of chitons. With few exceptions the illustrations are good and should enable the amateur to identify his finds. Ricketts's descriptions are interesting and informative. Size, habits and geographical range are given.

The book is well printed, with a good index. John Steinbeck has written a foreword. N. B. EALES

\section{Ribonucleoproteins and Ribonucleic Acids}

Preparation and Composition. Prof. Frank Worthington Allen. Pp. xii +192. (Amsterdam and New York: Elsevier Publishing Co., 1962.) 35s.

THIS book gives a selection from the literature of methods for the isolation of ribonucleic acids and ribonucleoproteins. The experimental procedures are presented in detail together with data on the analytical composition of the preparations. The book is written rather as a historical commentary on the development of preparative methods beginning with Altmann's isolation of yeast ribonucleic acid in 1889. Consequently many chapters are given to very detailed descriptions of procedures, which, although of historical interest, are known to result in extremely degraded nucleic acids and have long since been abandoned.

There is surprisingly little attempt to critically evaluate the methods in terms of present knowledge of the size and structure of ribonucleic acids. Only one reference is given to the molecular weight of a virus ribonucleic acid; it is that obtained on a degraded sample from tobacco mosaic virus in 1942.

One chapter reviews the distribution of the minor nucleotide components or ribonucleic acids. It is curious to find here no mention of the work of W. E. Cohn and his collaborators on the isolation and identification of 5 ribosyl uracil.

As a collection of nucleic acid preparative procedures the book should, however, be quite useful to those engaged in this field.
J. D. Sмттн 